\title{
Finance Planning In The University Using Information Methodology "ARIS"
}

\author{
Irine E. Nikulina \\ Department of Management \\ National Research Tomsk Polytechnic University \\ Tomsk, Russia \\ nie@tpu.ru \\ Elena A. Ershova \\ Department of Management \\ National Research Tomsk Polytechnic University \\ Tomsk, Russia \\ elkaershova@gmail.com
}

\author{
Aleksey A. Tarabanovsky \\ Department of «Tomskenergosbyt» \\ Tomsk, Russia \\ tarabanovsky@ensb.tomsk.ru
}

\author{
Anatoliy A. Zemtsov \\ Department of Finance and Accounting \\ National Research Tomsk State University \\ Tomsk, Russia \\ _finans_@sibmail.com
}

\begin{abstract}
- to organize an effective system of financial planning of autonomous educational institution of higher education it is required to use special planning and control procedures which are drawn up using the author's techniques. These procedures allow to optimize the process of financial planning and the process of control of the implementation of the university budget at all levels of consolidation. Designed for this purpose model of decision-making system, according to the methodology of the design of integrated information systems, is aimed at improving the financial planning process, by means of accumulation of information that contains information only about the correct management decisions.
\end{abstract}

Keywords-effective system of university finance planning, methodology for information system design, models of organization of financial flows, information flows planning process, centers of financial income and expenses, centers of financial activity.

\section{INTRODUCTION}

For the organization of an effective system of financial planning of autonomous educational institution of higher education it is required to use special planning and control procedures which are drawn up using the author's techniques. These procedures allow to optimize the process of financial planning and the process of control of quality of implementation of the university budget at all levels of consolidation. In this case, you can use one of the modern business processes description standards: methodology «ARIS» (Architecture of Integrated Information Systems) [14]

Current trends in the field of finance and economy create the preconditions for the use of new high-performance business processes description standards. In this regard, we propose to use the methodology «ARIS» for the construction of an integrated information system, financial planning system of autonomous educational institution of higher professional education, adapting its model in relation to the university. The presented methodology is a key element that serves to integrate the separate processes: from the collection and processing of raw data to the monitoring, controlling and financial analysis into a single university financial planning system. Methodology «ARIS» - this is a full-fledged too consisting of a system of models focused on the mission of the university, which serves not only to enhance the effectiveness of the organization, but also directly for organization of logically thought out and accurate mechanism of functioning and development of the university.

\section{MODELS BUDGETING FINANCIAL FLOWS}

Note that not all units of the university's financial structure are a source of income. In particular, activities related to the provision of the educational process, for example, in terms of supply of electricity and heat of buildings and structures owned by the educational institution, in essence, are cost generating. The same can be said about accounting, information and other support units of the university. Without such units the normal educational process is unthinkable. Although formally they do not generate revenues, they still serve university's mission. In addition, financial activity of the university is acting as a link of all departments of the university, because financial flows in varying degrees, cover all areas of functioning and development of the university. That is why the distribution and control of funds in the university becomes a priority. In this connection, we propose to define the centers of financial income (CFI) and centers of financial expenses (CFE) in the autonomous university of presenting them in the model «CFI-CFE». In Figure 1 a model «CFI-CFE» is represented in part of financial income of autonomous university, where CFI are in their respective boxes with selected font. Under each CFI rectangle there is and explanation of major revenue sources, grouped by type of activity. Figure 2 shows the model «CFI-CFE», which reflects the structure of financial expenses. In fact, the same areas of activity act as centers of financial income and expenses, but still centers of financial expenses also include units that can not be a source of any income, but have important functions in the university. In particular, these units include: administrative staff, accountants, financial services, office, human resources and others. 
By using the model «CFI-CFE» it becomes clear how revenues are generated, who is responsible for the main financial flows for each of the activities and what directions the university funds are spent. However, detailed information on the structure of each CFE expenditure for the model «CFICFE» is not available, therefore, in order to eliminate this drawback and to ensure efficient functioning of the University, it is recommended to use wide tools of controlling [5]. In addition, for organization of effective system of financial planning in the university it is necessary to choose the financial responsibility centers (CFR) and the formulation of the criteria for this choice. It is noteworthy that the centers of financial income and expenses mentioned above may not be the centers of financial responsibility, as the latter include only those groups of units and departments that have a real possibility to earn and expend funds under the supervision of their immediate supervisor. Ideally, all three considered financial centers (CFI, CFE, CFR) must be the same for the same type of activity. In reality this does not happen, because the organization of university management is mainly built on the basis of a linear organizational structure, rather than a matrix or divisional. In a transitional phase to a divisional organizational structure of the university management, it may useful to assign the head of financial activities to be the center of financial responsibility. In this case, the leaders of all major types of activities (local CFR) remain self-sufficient in meeting all current management issues, including financial, except changes in set contributions to the overall university development fund, which is necessary to maintain the normal functioning of the institution and ensure the current cost structure of CFE.

The amount of such contributions is determined by the head of the financial activities who, acting as head of the global CFR distributes financial flows within the university. $\mathrm{He}$ is also head of CFE, supervising units and departments.

Selection of priority areas and identification of special regime of their functioning is also of great importance in the organization of financial flows. Under the priority areas, we assume the areas which provide the best result according to the selected development goals. Examples of generic assessment criterion of achievement of the objectives may be different, however, for the university, as such a criterion, you can use the "return on investment". According to the program of development of the university initially local priorities are selected and then they are distributed, and (or) are combined by activity into the global. Return on capital shows the impact of each ruble invested in selected priority areas, where the latter can be a separate project in the field of educational activity, science, innovation, investment, marketing, PRactivity, another business, or a group of such projects. As a rule, in the priority areas there is a weighty share of the thirdparty interest of the state, investors, partners and other individuals and organizations that, in fact, provide partial or full funding for ongoing projects.

\section{Centers of financial income (CFI)}

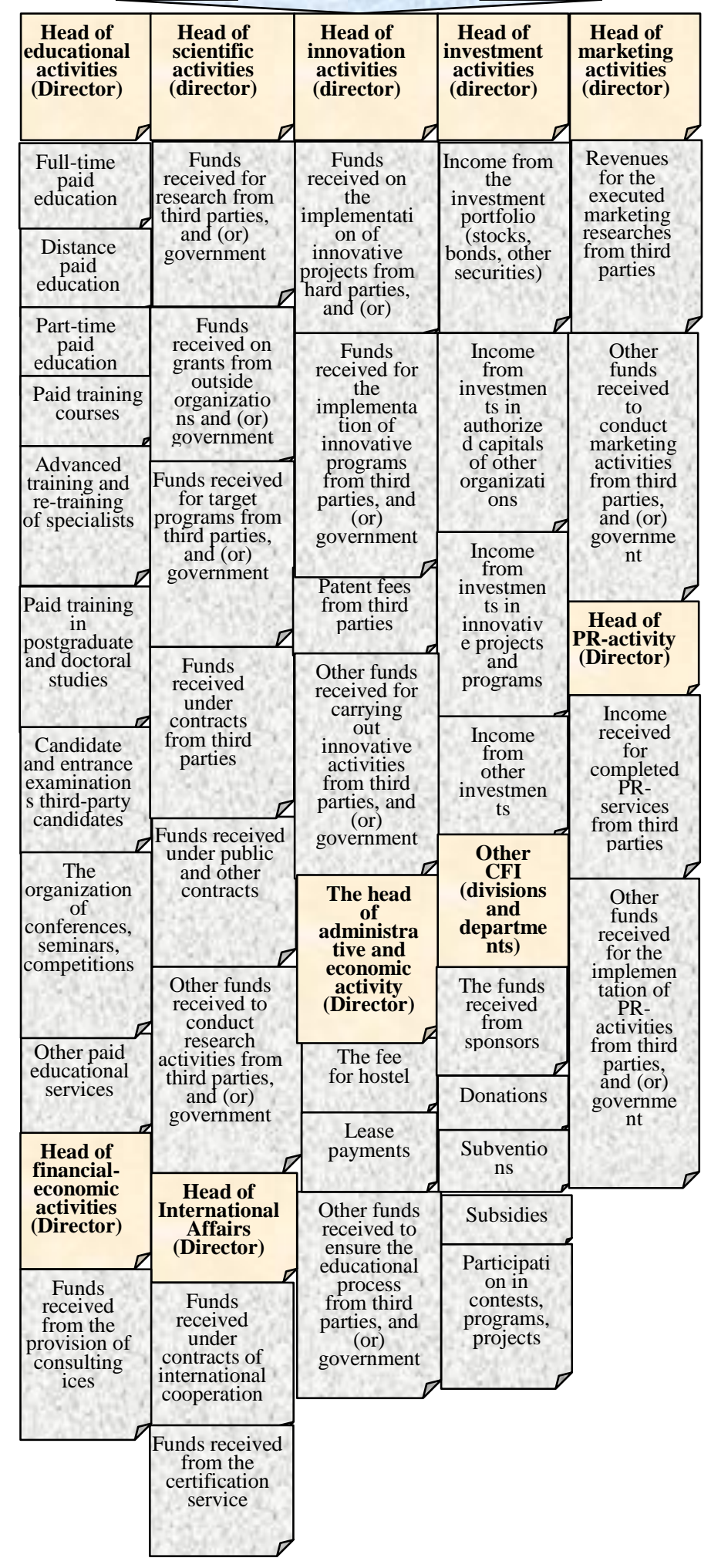

Fig.1. «CFI-CFE» model. University centers for financial income 
As part of the ARIS technologies should be an ongoing system of decision-making "SDM" (figure 3), which efficiency is determined by goals orientation and properly structured information flows (figure 4). Thus, there is a consistent structuring of information and feedback information communication is carried out in the management of financial planning process in the university. Under the process of financial planning realize continuous operation of economic services of CFR on the formation and distribution of financial flows within the institution, control over the use of financial resources in CFE and the implementation of income plan in CFI [6].

\begin{tabular}{|c|c|c|c|c|}
\hline \multicolumn{5}{|c|}{ Centers of financial expenses (CFE) } \\
\hline \multicolumn{3}{|c|}{$\longrightarrow$} & \multicolumn{2}{|c|}{$\square$} \\
\hline $\begin{array}{l}\text { Head of } \\
\text { educationa } \\
\text { l activities } \\
\text { (Director) }\end{array}$ & $\begin{array}{l}\text { Head of } \\
\text { scientific } \\
\text { activities } \\
\text { (director) }\end{array}$ & $\begin{array}{l}\text { Head of } \\
\text { innovation } \\
\text { activities } \\
\text { (director) }\end{array}$ & $\begin{array}{l}\text { Head of } \\
\text { investment } \\
\text { activities } \\
\text { (director) }\end{array}$ & $\begin{array}{l}\text { Head of } \\
\text { marketing } \\
\text { activities } \\
\text { (director) }\end{array}$ \\
\hline $\begin{array}{l}\text { Divisions and } \\
\text { Departments }\end{array}$ & $\begin{array}{c}\text { Divisions } \\
\text { and } \\
\text { Departments }\end{array}$ & $\begin{array}{c}\text { Divisions } \\
\text { and } \\
\text { Departments }\end{array}$ & $\begin{array}{c}\text { Divisions } \\
\text { and } \\
\text { Departments }\end{array}$ & $\begin{array}{l}\text { Support of all } \\
\text { marketing } \\
\text { activities }\end{array}$ \\
\hline \multirow{2}{*}{$\begin{array}{l}\text { Institutes and } \\
\text { Departments }\end{array}$} & & & & \\
\hline & $\begin{array}{l}\text { Support for } \\
\text { R\&D, }\end{array}$ & $\begin{array}{l}\text { Support for } \\
\text { innovative }\end{array}$ & Management & $\begin{array}{l}\text { Other units } \\
\text { of the }\end{array}$ \\
\hline \multirow{2}{*}{$\begin{array}{c}\text { Other units of } \\
\text { the } \\
\text { organizational } \\
\text { structure }\end{array}$} & $\begin{array}{l}\text { grants, } \\
\text { targeted } \\
\text { programs, } \\
\text { contracts }\end{array}$ & $\begin{array}{l}\text { projects and } \\
\text { programs }\end{array}$ & 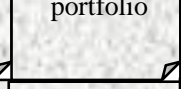 & I structure \\
\hline & & Other units & & Head of PR- \\
\hline \multirow{3}{*}{$\begin{array}{l}\text { Head of } \\
\text { financial- } \\
\text { economic } \\
\text { activities } \\
\text { (Director) }\end{array}$} & $\begin{array}{l}\text { Other units } \\
\text { of the } \\
\text { organization }\end{array}$ & $\begin{array}{l}\text { of the } \\
\text { organization } \\
\text { al structure }\end{array}$ & $\begin{array}{l}\text { investments } \\
\text { in the } \\
\text { authorized } \\
\text { capitals of }\end{array}$ & (Director) \\
\hline & & & other & Support of all \\
\hline & $\begin{array}{l}\text { Head of } \\
\text { Internation }\end{array}$ & & & \\
\hline $\begin{array}{l}\text { Divisions and } \\
\text { Departments }\end{array}$ & $\begin{array}{l}\text { Internation } \\
\text { al Affairs } \\
\text { (Director) }\end{array}$ & $\begin{array}{c}\text { e and } \\
\text { household } \\
\text { activity } \\
\text { (Director) }\end{array}$ & $\begin{array}{c}\text { Securing } \\
\text { investments in } \\
\text { innovative } \\
\text { proiects and }\end{array}$ & $\begin{array}{c}\text { Other units of } \\
\text { the } \\
\text { organizational }\end{array}$ \\
\hline $\begin{array}{c}\text { Consulting } \\
\text { centers }\end{array}$ & \begin{tabular}{|c|} 
Certification \\
centers
\end{tabular} & Overall & & icture \\
\hline Taxation & $\begin{array}{l}\text { Other units } \\
\text { of the } \\
\text { organization } \\
\text { al structure }\end{array}$ & $\begin{array}{l}\text { support of } \\
\text { the } \\
\text { educational } \\
\text { process }\end{array}$ & \begin{tabular}{|c|} 
Other units of \\
the \\
organizationa \\
1 structure
\end{tabular} & \\
\hline \multirow{3}{*}{$\begin{array}{c}\text { Other units of } \\
\text { the } \\
\text { organizational } \\
\text { structure }\end{array}$} & $\begin{array}{c}\text { Head of } \\
\text { administrat } \\
\text { ive activity } \\
\text { (Director) }\end{array}$ & $\begin{array}{l}\text { Other units } \\
\text { of the } \\
\text { organization } \\
\text { al structure }\end{array}$ & $\begin{array}{c}\text { Other CFA } \\
\text { (divisions and } \\
\text { departments) }\end{array}$ & \\
\hline & & & Participati & \\
\hline & $\begin{array}{l}\text { Administrativ } \\
\text { staff }\end{array}$ & & $\begin{array}{l}\text { on in } \\
\text { competitio }\end{array}$ & \\
\hline $\begin{array}{r}\mathrm{O} \\
\text { orgar }\end{array}$ & $\begin{array}{l}\text { r units of } \\
\text { ational str }\end{array}$ & & $\begin{array}{c}\text { Other units } \\
\text { of the } \\
\text { organization } \\
\text { al structure }\end{array}$ & \\
\hline
\end{tabular}

Fig.2. «CFI-CFE» model. University centers of financial expenses

\section{MODELS OF INFORMATION FLOWS}

The decision making process includes a set of activities and actions aimed at achieving the most effective result in established tasks by selecting the optimal variant from the possible alternatives. In the process of estimation of the result time factor plays an important role, because for some decision options, the result can be significantly extended in time. An integral part of this process is to check the focus on the local and global goals. If negative information flow №5 takes place, the system returns to the choice of an alternatives from a bank of decisions. If information flow is positive - it transfers, you to the analysis of results. The last is the formation of criteria for assessing the quality the data obtained and determining the extent of the actual performance of the task. In addition, from the analysis of the decisions made follows the flow of information №6 that is the most significant (archival) and returns the system to its original state, but in a somewhat different form, with higher "immunity."

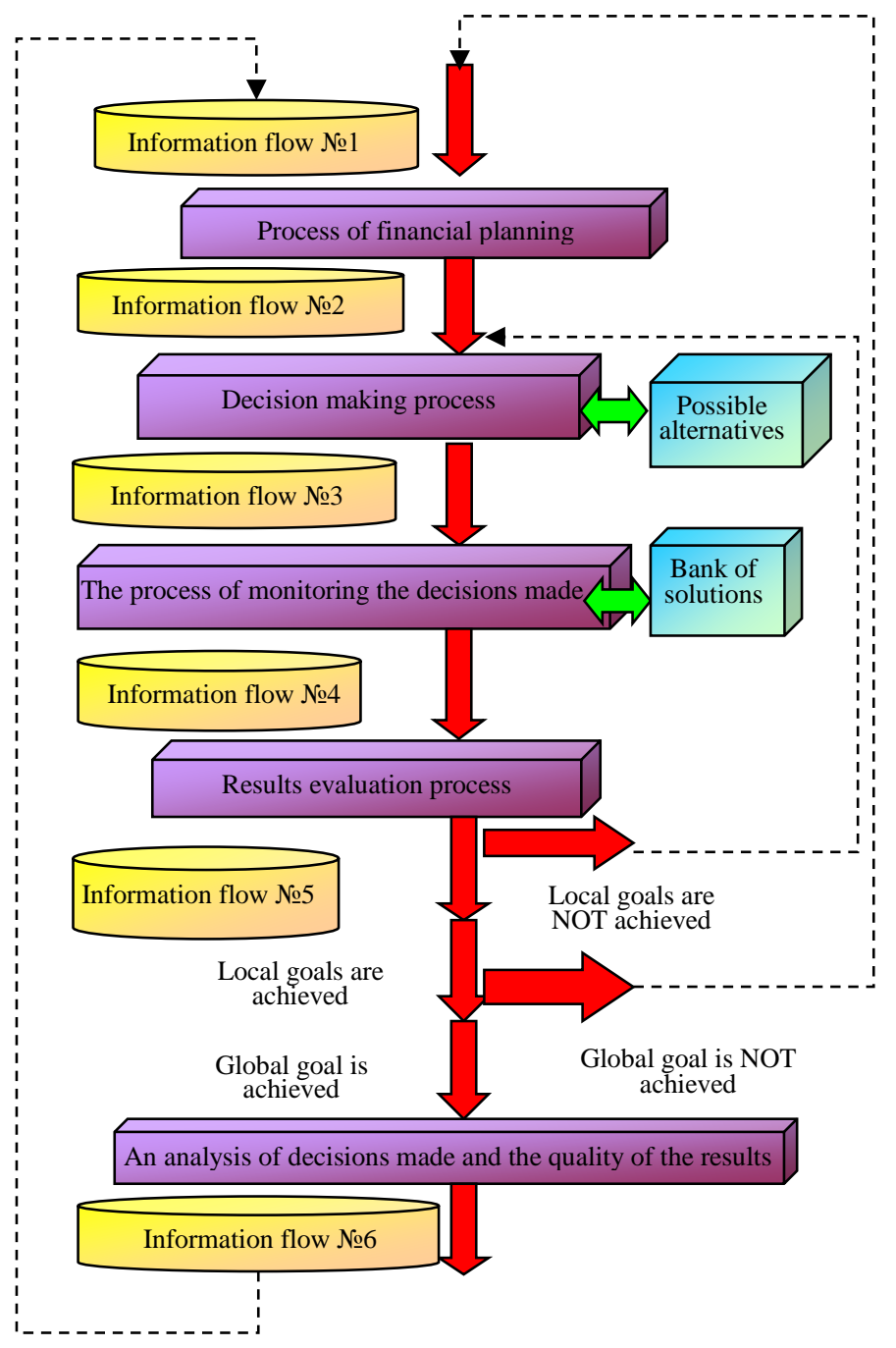

Fig. 3. «SDM» Model at the University

Head of CFR, to make decisions on implementation of a project(s), has to evaluate the readiness of units to fulfill the task taking into consideration not only financial but also nonfinancial resources. To do so he has to look at a number of issues: whether staff qualification is sufficient for the task, how they are engaged in ongoing work at the moment and whether they are able to take on additional burden, how far the project is a venture and what are the real risks of no return on investment. It is important to understand that no always financial goals are to be primary. However, in the proposed 
SDM model, the process of financial planning is based on the development goals and is used as a tool to overcome the uncertainty in the future. Thus, achieving financial results, we also achieve global goals and fulfill the mission of the university.

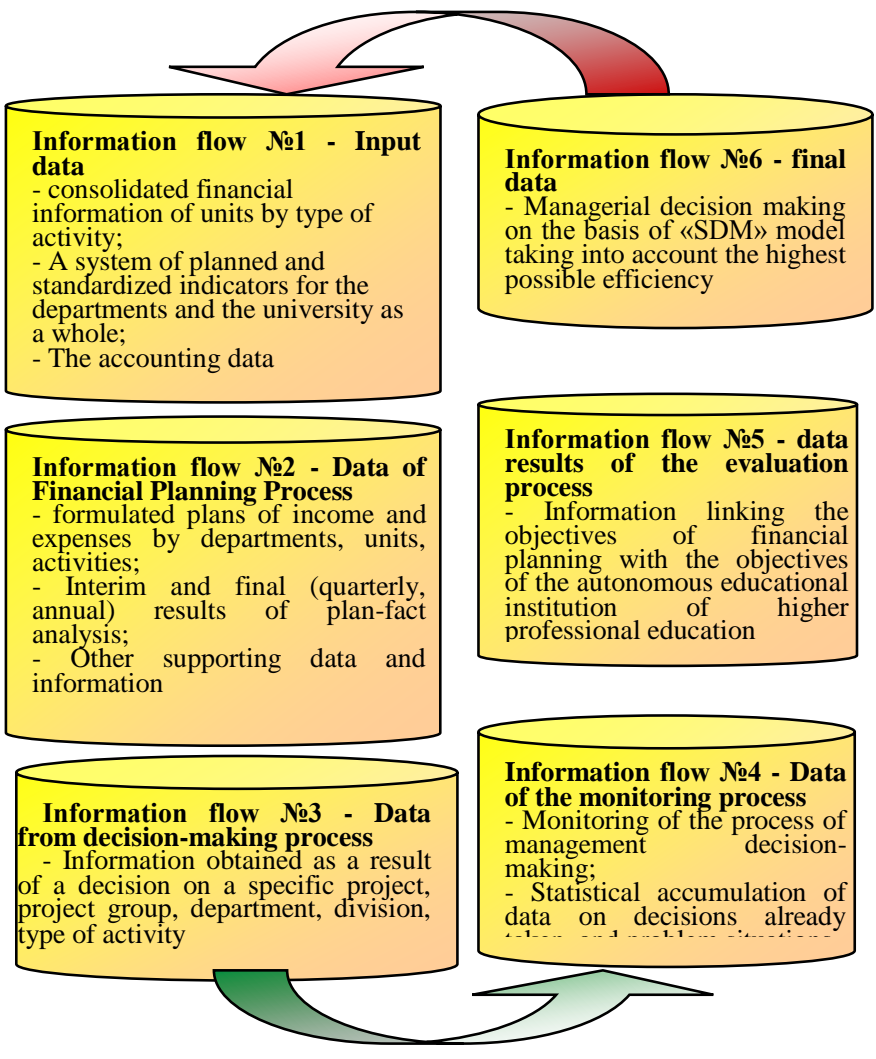

Fig. 4. Information flows in «SDM» model

\section{FINANCIAL INDICATORS OF THE PROJECT IN UNIVERSITY}

Based on the above mentioned data, projects are ranked and a bank of possible solutions for them is formed. Bank of solutions for each of the projects is represented by a series of alternatives. Among all solutions it is possible to select mutually exclusive variants (different not only in the level of financing) and different planned workloads (different mostly in the level of financing). In the first case, analysis and estimation of packages of solutions (alternatives) is implemented using the method of analysis of policy and development strategy of the university, with evaluation of possible consequences of each variant realization in terms of financial and non-financial goals. In the second case, analysis and estimation are conducted based on "cost-benefit" approach, which assumes mandatory definition of the minimal (below which it is impossible to achieve planned general goals), maximum and one or several intermediate levels of financing.
Which of the decisions to be made by the head, depends on the nature of the decisions themselves, their focus on the local and global goals of the university, rector policy, other internal and external factors, and psychological peculiarities of the head of CFR. Human factor in decision-making is overwhelming, if the head is inclined to adventurism, the logic of the selection of a variant of the decision may not be so clear. However, as the experience of local and foreign researchers shows, senior managers and their assistants often prefer rationalism to their intuitive urges [7].

Results of the decisions maid can be evaluated after effective period of the project is over. This period is set for each project and each bank of solutions. It is also on of the influencing factors in selection of alternatives. Effective period is different from the payback period of the project and is defined by the business plan. As a rule, for major projects, firs effective limit is one year, for minor projects -1 month. After this period, the responsible head of CFR, together with the Project Manager shall decide on the continuation (stabilization, development) or completion (reduction, elimination) of this project(s). In the process of results assessment, it is important to establish the degree of achievement of local and global goals for specific project, group of projects, direction and the entire university. In this case target indicators may be of economic and non-economic character, and will fully depend on the nature of the project (fig.5).

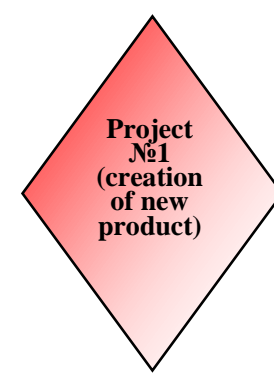

1. The degree of implementation of technical or other tasks (in the initial stages of the project). 2. Return on invested capital (at all stages, in the case of the product realization).

3. The proportion (percentage) of financial income (at all stages, in the case of the product realization) of the project in the consolidated budget of the project group, the direction of activity, of all university.

4. Indicators of investment attractiveness of the project (net present value NPV, discounted payback period DPP project - all depending on the considered effective limit).

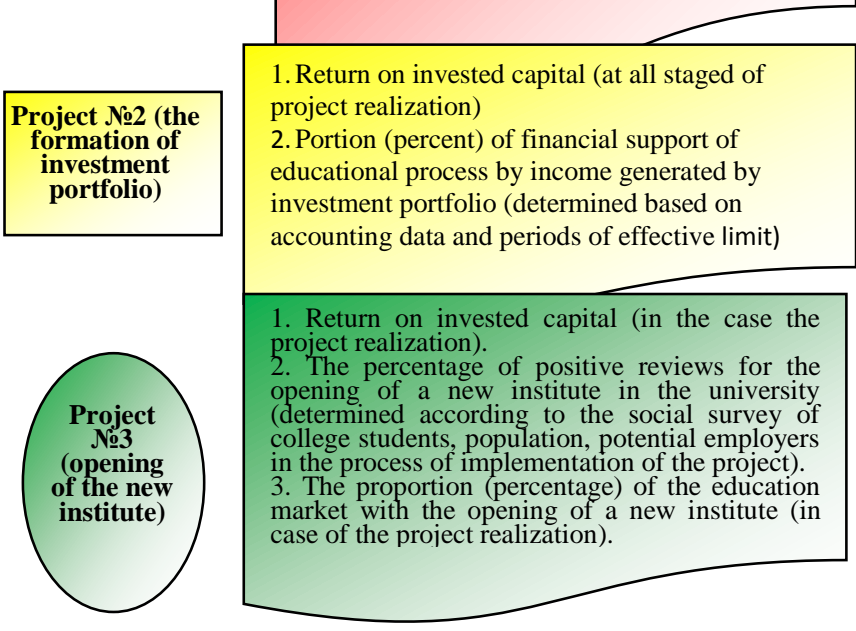

Fig.5. Local target indicators by projects 
All of the mentioned on figure 5 local goal indicators, reflecting the degree of local goals achievement, are inseparably linked with global target indicators, which in their turn, describe level of achievement of the global goal and the mission of the university. As a global target indicator, it is suggested to use university's rating, based on internal and external assessment. Internal assessment is the assessment of influence of realization (degree of realization) of project(s) on its own (internal view of the situation). External assessment is the assessment of the same nature done by outside organizations (external view of the situation). When established values of target indicators are achieved, the SMD takes a step forward and moves on to the process of analysis of decisions made and quality of obtained results, if not - it takes a step backwards (feedback) to alternatives selection or to analysis of input financial information in order to determine causes of failure in achievement of established goals.

In the process of analysis of decisions made about project(s) and quality of obtained results, important information is elicited, which is reflected in the financial plan at all levels of consolidation and most importantly - strategic decision is assessed qualitatively in the time period. Thus obtained experience is accumulated and is used in the process of further development of the university.

\section{ACKNOWLEDGEMENT}

The final stage of "ARIS" methodology presentation for organization of effective system of university financial planning is formation of relationships, necessary for coordinated exchange of information between considered models and key elements of financial planning system. Development of internal and external information nets is implemented even at the stage of organization of information support, although consistency check of information flows is done at this stage. It is especially important to have consistency between databases, special software, other software used by departments and divisions as it directly relates to speed and adequacy of transmitted and used information.

Thus, in order to organize effective system of financial planning in the university, using ARIS methodology, it is necessary to consistently implement an interdependent system, focused on university mission, which allows management to make adequate decisions in constantly changing conditions of external and internal environment.

\section{REFERENCES}

[1] S.M. Kovalev, V.M. Kovalevю, "Methodologies if description of business processes ORACLE, BAAN, ARIS", Directory economist, 2007, №1, pp. 24-33

[2] Barry J. Epstein, Steven M. Bragg, Ralph Nach. "Wiley GAAP: Interpretation and Application of Generally Accepted Accounting Principles”, 2009, Wiley, John \& Sons, Incorporated, 2008, 1440 pp. (GAAP-analysis)

[3] C. William Garner. "Education Finance for School Leaders: Strategic Planning and Administration", Prentice Hall, 2003, 320 pp.

[4] Chandan Sengupta. "Financial Modeling Using Excel and VBA (Wiley Finance Series)", Wiley, John \& Sons, Incorporated, 2004, 657 pp.
[5] I.E. Nikulina "Controlling System", Research University Higher education in Russia, № 2, 2015, pp. 24-29.

[6] I.E. Nikulina, A.A.Tarabanovsky "Monitoring Analysis and monitorcriteria in the system of financial planning of the Autonomous Educational Institution of Higher Professional Education”, Fundamental Research, 2009, № 1, pp. 82-88.

[7] Philip G. Altbach, Patricia J. Gumport, Robert O. Berdahl. "American Higher Education in the Twenty-First Century: Social, Political, and Economic Challenges", Hopkins Fulfillment Services, 2005, 568 pp.

[8] Asian Paints consolidated net profit for the quarter increases by $11.8 \% / /$ Focus on Powder Coatings, Volume 2015, Issue 3, March 2015, pp. 2-8

[9] Aziz Jaafar, , John Thornton (2015). "Tax Havens and Effective Tax Rates: An Analysis of Private versus Public European Firms // The International Journal of Accounting", Volume 50, Issue 4, December 2015, pp. 435-457

[10] I. P. Nuzhina, O. B. Yudakhina, E. I. Kotik , E. G. Matyugina "Ecologization of Management Functions as a Factor of Sustainable Development of Construction Industry in Russia”, ICEM2015, 2015, pp. 414-417

[11] K.A.Bannova, I.N.Dolgih, A.B.Zhdanova, N.V. Pokrovskaya, "Developing The Competitive Advantage Of Companies And Regions By The Creation Of Consolidated Groups Of Taxpayers", IBIMA, 2015, pp. 834-841.

[12] N. Chistyakova, V. Spitsin, T. Gromova, N. Shabaldina, A. Dudnikova, "Comparative Investment Analysis of Industries Development in Russia and Germany". Proceedings of the 2015 International Conference on Education Reform and Modern Management, Atlantis Press; 2015; Available from: http://dx.doi.org/10.2991/ermm-15.2015.98 
